DOI : $10.14746 / \mathrm{pp} .2015 .20 .4 .8$

Tadeusz KAMIŃSKI

Warszawa

\title{
Gminna pomoc społeczna - ćwierć wieku transformacji
}

\begin{abstract}
Streszczenie: Artykul poświęcony jest refleksji nad dwudziestopięcioleciem funkcjonowania pomocy społecznej w strukturach odrodzonego samorządu gminnego. Najpierw ogólnie zostało ukazane znaczenie procesów decentralizacji we współczesnej pomocy społecznej. Następnie przedstawiono pokrótce polskie doświadczenia gminnej pomocy społecznej, sięgające uchwalonej w 1923 roku ustawy o opiece społecznej. W dalszej kolejności zaprezentowana zostala kluczowa rola ustawy o pomocy społecznej z 29 listopada 1990 roku, skutki reformy administracyjnej wdrożonej 1 stycznia 1999 roku oraz aktualne wyzwania stojące przed gminną pomocą społeczną.
\end{abstract}

Słowa kluczowe: gmina, pomoc społeczna, decentralizacja

D wudziestopięciolecie restytucji samorządu terytorialnego w Polsce to zarazem jubileusz odrodzonej gminnej pomocy społecznej. Tak jak podstawową jednostką samorządu terytorialnego jest gmina, tak też podstawową strukturą publicznej pomocy społecznej jest ośrodek pomocy społecznej obligatoryjnie tworzony na szczeblu samorządu gminnego. Najbardziej charakterystyczną cechą gminnej pomocy społecznej jest próba sprostania realizacji zadań ustawowo określonych jako własne, przy jednoczesnym spełnianiu funkcji wykonawcy zadań zleconych z zakresu administracji rządowej. Warto poświęcić uwagę temu problemowi właśnie w kontekście rozważań nad doświadczeniami polskiej samorządności terytorialnej, gdyż jak ujęli to w tytule jednego ze swych tekstów Piotr Błędowski i Paweł Kubicki pomoc społeczna jest główną instytucją socjalną na szczeblu lokalnym (Błędowski, Kubicki, 2009). W przedłożeniu ukazane zostanie najpierw ogólnie znaczenie procesów decentralizacji we współczesnej pomocy społecznej. Następnie przedstawione zostaną pokrótce polskie doświadczenia gminnej pomocy społecznej, sięgające uchwalonej w 1923 roku ustawy o opiece społecznej. W dalszej kolejności zaprezentowana będzie kluczowa rola ustawy o pomocy społecznej z 29 listopada 1990 roku, skutki reformy administracyjnej wdrożonej 1 stycznia 1999 roku oraz aktualne wyzwania dla gminnej pomocy społecznej.

\section{Decentralizacja w pomocy społecznej}

Pomoc społeczna jest instytucją ściśle związaną ze strukturami współczesnych państw rozwiniętych, nazywanych zwykle welfare states. Ich istotajest bowiem publiczna odpowiedzialność za zapewnienie zaspokojenia niezbędnych potrzeb życiowych obywateli, którzy nie mogą uczynić tego we własnym zakresie lub z pomocą swoich bliskich. W szerszym ujęciu, proponowanym choćby przez Waltera A. Friedlandera pomoc społeczna pojmowana jest jako zorganizowany systemem ,świadczeń i instytucji spo- 
łecznych mających za zadanie dopomóc jednostkom i grupom w osiągnięciu zadowalającego poziomu życia, stanu zdrowia, stosunków osobistych i społecznych, co pozwoli w pełni rozwinąc im możliwości, oraz będzie sprzyjało pomyślności, pozostając w harmonii z potrzebami ich rodzin i otoczenia" (cyt. za: Skidmore, Thackeray, 1996, s. 15-16). W węższym ujęciu z kolei pomoc społeczna rozumiana jest jako „katalog dóbr (zasiłki, pomoc w naturze, usługi) świadczonych przez właściwe organizacje, przede wszystkim publiczne, osobom, które znajdują się w trudnej sytuacji życiowej i w związku z tym potrzebuja pomocy" (Kaźmierczak, 2000, s. 144). Niewątpliwie jednak mamy do czynienia w tym przypadku z instytucją polityki społecznej państwa, co wprost zostało zapisane w art. 2 ust. 1 obowiązującej obecnie ustawy z dnia 12 marca 2004 roku o pomocy społecznej. Ma być ona realizowana we współpracy z organizacjami społecznymi, pozarządowymi, Kościołami i innymi związkami wyznaniowymi oraz osobami fizycznymi i prawnymi (art. 2 ust. 2), ale za organizację systemu pomocy społecznej pozostaje odpowiedzialne państwo. W konsekwencji przyjmuje ono na siebie finansowanie zadań uznanych za konieczne do realizacji w sferze pomocy społecznej, a ponadto sprawuje nadzór i kontrolę nad organami i podmiotami wykonującymi zadania pomocy społecznej. Obok organów administracji rządowej odpowiedzialność za pomoc społeczną spoczywa głównie na jednostkach samorządu terytorialnego. Można zatem za Wojciechem Maciejko powiedzieć, że takie formalnoprawne umocowanie pomocy społecznej powoduje, iż ma ona charakter instytucji publicznej (Maciejko, 2009, s. 29-30).

Zdecentralizowany charakter pomocy społecznej traktowany jest jako główna cecha charakterystyczna tej instytucji. Choć bowiem istnieje wiele zróżnicowanych modeli pomocy społecznej, to jednak wspólne dla nich jest, że „pomoc społeczna pozostaje w gestii władz lokalnych, co powoduje, że w jednym państwie może funkcjonować od kilku do kilkudziesięciu różnych systemów świadczeń opiekuńczych" (Księżopolski, 1999, s. 180). Zróżnicowania mogą zatem istnieć nie tylko pomiędzy poszczególnymi państwami, ale także wewnątrz nich. Warto przy tym zauważyć, że zdecentralizowaniu administrowania zadaniami niekoniecznie towarzyszyć musi decentralizacja ich finansowania i odwrotnie. Nawet jednak dalece zdecentralizowana pomoc społeczna pozostaje nadal instytucją publiczną (Kamiński, 2012, s. 80).

Pojęcie decentralizacji w pomocy społecznej oznaczać może jednakże różne rodzaje konkretnych działań, realizowane na różnych poziomach funkcjonowania państwa i wprowadzane przy użyciu różnorodnych strategii. Dość wnikliwą analizę tych różnych ujęć i wymiarów decentralizacji przeprowadził między innymi Jerzy Krzyszkowski (2005, s. 89-98) i do jego ustaleń wypada odwołać się w tej części niniejszego tekstu. W najogólniejszym ujęciu, decentralizacja oznacza zatem proces, w ramach którego świadczenia i usługi socjalne przenoszone są ze szczebla rządu centralnego na mniejsze, lokalne właśnie jednostki administracji czy agencje w przekonaniu, że znajdują się one bliżej adresatów tych świadczeń i usług. W praktyce tak rozumiana decentralizacja w sferze socjalnej może oznaczać: a) lokalizację usług na niższym poziomie; b) integrację tych usług w sensie świadczenia ich przez jedną lokalnąjednostkę administracyjną; c) delegowanie władzy zarządzającej i związanej z nią odpowiedzialności jak najbliżej „,pierwszej linii" oraz d) demokratyzację władzy lokalnej, przez co należy rozumieć przekazanie społecznościom lokalnym władzy politycznej. Efektem decentralizacji powinno być sprawniejsze rządzenie, zwiększenie kontroli społecznej nad władza, kształtowanie wię- 
kszej odpowiedzialności za własne sprawy w społecznościach lokalnych oraz zdjęcie z państwa troski o sprawy społeczne (Ibidem, s. 89). W tym ostatnim przypadku pomoc społeczna pozostaje instytucją polityki państwa, ale zmienia się szczebel, na którym spoczywa bezpośrednia odpowiedzialność za realizację celów tej polityki.

\section{Polskie doświadczenia (tradycje) gminnej pomocy społecznej}

W odniesieniu do polskiej pomocy społecznej można zasadnie mówić o istnieniu pewnych tradycji decentralizacyjnych. Sięgają one uchwalonej 16 sierpnia 1923 roku ustawy o opiece społecznej, choć jak słusznie zauważa Dariusz Zalewski „w ujęciu historycznym, instytucje opieki i pomocy społecznej zawsze ksztaltowały się w środowiskach lokalnych jako dobrze osadzone w lokalnych realiach (systemach wartości, strukturze interesów) reguły gry mające służyć zarówno interesom wspólnoty, jak i znajdującym się w potrzebie jednostkom" (2005, s. 81). Podstawa jednakże tworzenia systemu wsparcia potrzebujących w skali ogólnokrajowej, ze wskazaniem zakresu odpowiedzialności państwa oraz władz lokalnych była w istocie dopiero przywołana ustawa z 1923 roku. Obowiązki związane $\mathrm{z}$ bezpośrednim wykonywaniem zadań z zakresu opieki społecznej zostały w niej przypisane związkom komunalnym, a wśród nich kluczową rolę odgrywać miały gminy. Zgodnie $\mathrm{z}$ art. 5 tejże ustawy ,gminy wiejskie i miasta, nie wydzielone ze związku komunalnego powiatowego, sprawują zasadniczo opiekę pozazakładową, zakładową zaś o tyle, o ile fundusze gminne pozwolą na założenie i utrzymanie zakładu". Miasta wydzielone ze związku powiatowego miały sprawować zarówno opiekę zakładową, jak i pozazakładową. Rolą związków powiatowych miało być uzupełnianie i wspieranie gmin w realizacji zadań opiekuńczych, zaś rolą wojewódzkich zwiazków komunalnych uzupełnianie opieki sprawowanej przez związki komunalne i miasta wydzielone ze związków komunalnych. Prawo do opieki ze strony gminy nabywał ten, kto mieszkał na terenie gminy co najmniej jeden rok (art. 8). Utrata zaś prawa do opieki była skutkiem nabycia go w innej gminie lub nieuzasadnionej trwałej jednorocznej nieobecności na terenie gminy (art. 9).

Znaczącą kwestią było finansowanie zadań opieki społecznej. Koszty te w myśl ustawy powinny być pokrywane przede wszystkim z budżetów związków komunalnych (art. 16). Warto w związku z tym przytoczyć w dosłownym brzmieniu art. 17 ustawy: „W razie uchylenia się związków komunalnych od wstawienia do budżetu lub uchwalenia poza nim wydatków, do których pokrycia są w myśl niniejszej ustawy zobowiązane, wprowadzi władza nadzorcza, na wniosek właściwego organu Ministerstwa Pracy i Opieki Społecznej, odpowiednie kwoty do budżetów odnośnych związków komunalnych. W przypadkach wyjątkowych, gdy związki samorządowe nie są w finansowej możności wypełniać obowiązków z ustawy niniejszej wynikających, Minister Opieki Społecznej w porozumieniu z Ministrem Spraw Wewnętrznych i Ministrem Skarbu udziela na wniosek właściwego wojewody odpowiedniej subwencji z funduszów państwowych na pokrycie tych potrzeb". Tak więc ustawa uwzględnia możliwość wystąpienia sytuacji, w których środki budżetowe władz lokalnych mogą nie wystarczyć dla pokrycia niezbędnych wydatków na zadania nałożone ustawą. Innym, obok wspomnianej subwencji, rozwiązaniem mającym wesprzeć związki komunalne w realizacji zadań jest możliwość 
łączenia ciał samorządowych. Zgodnie z art. 19 „dla ulżenia swym obowiązkom opiekuńczym, tudzież dla skuteczniejszego sprawowania opieki społecznej, mogą dobrowolnie łączyć się we wspólnąjednostkę administracyjno-opiekuńczą gminy tego samego związku komunalnego powiatowego, gminy różnych związków komunalnych powiatowych oraz różne związki komunalne powiatowe".

Sposób finansowania zadań opieki społecznej, czyli de facto scedowanie tej odpowiedzialności całkowicie na poziom związków komunalnych stanowił jedną z przyczyn trudności z pełną ich realizacją. Podobnie jak dzisiaj, zróżnicowanie poszczególnych jednostek samorządowych pod względem ich zamożności w decydujący sposób wpływa na zakres i jakość wypełniania zadań. Jednakże zwraca się uwagę także na inne przyczyny tego stanu rzeczy w odniesieniu do funkcjonowania omawianej tu ustawy. Otóż, istotną rolę w ówczesnym systemie opieki społecznej właśnie na poziomie lokalnym mieli do odegrania tzw. opiekunowie społeczni. Nie byli to jednak profesjonalni pracownicy administracji lokalnej, lecz swego rodzaju osoby zaufania społecznego, które nie pobierały wynagrodzenia $z$ tytułu wykonywania obowiązków na rzecz gmin. $Z$ jednej strony miało to zapewniać lepsze rozeznanie potrzeb socjalnych, ale z drugiej pozwolić też na duży stopień indywidualizacji świadczeń. Ta jednak oparta była o uznaniowość opiekuna społecznego. Mógł on zatem odmówić przyznania świadczenia lub też przyznać je w minimalnej wysokości, wedle dość swobodnie wybranych, nieokreślonych formalnie kryteriów. Nie bez znaczenia jest też fakt, że w wielu gminach opiekunowie społeczni w ogóle nie podjęli działalności (Zalewski, 2005, s. 82-84).

Innym dość ważnym aspektem funkcjonowania lokalnej opieki społecznej w dwudziestoleciu międzywojennym było umożliwienie, a nawet promowanie współpracy administracji lokalnej z podmiotami, które współcześnie określamy mianem organizacji pozarządowych. Jak zwraca uwagę Jerzy Krzyszkowski, do głównych zasad prawa socjalnego w II Rzeczypospolitej obok powszechności dostępu i obligatoryjności świadczeń zaliczyć trzeba uspołecznienie, rozumiane właśnie jako współpraca sektora publicznego z organizacjami pozarządowymi (Krzyszkowski, 2005, s. 52). Organizacje te miały szczególnie znaczący udział w organizacji zakładowej opieki dla dzieci i młodzieży, ale generalnie w połowie lat trzydziestych ubiegłego wieku ,zdecydowana większość - 2/3 wychowanków i pensjonariuszy - korzystała ze wsparcia sektora pozarządowego, a jedynie około $1 / 3 \mathrm{z}$ bezpośredniej opieki i pomocy organizowanej przez związki komunalne (Zalewski, 2005, s. 75). Jak wynika z danych statystycznych dotyczących struktury finansowania organizacji pozarządowych, ważną, choć nie szczególnie znaczącą pozycję w ich budżetach, stanowiły subwencje związków komunalnych (Ibidem, s. 206). Nie była to zatem współpraca tak zinstytucjonalizowana jak odbywa się to współcześnie (np. poprzez zlecanie zadań w drodze konkursu ofert), niemniej jednak udział tych podmiotów w systemie opieki społecznej niewątpliwie odciążał związki komunalne zarówno w wymiarze organizacyjnym, jak i finansowym.

\section{Kluczowa rola ustawy o pomocy spolecznej z 29 listopada 1990 roku}

W okresie tzw. Polskiej Rzeczypospolitej Ludowej nie funkcjonował de facto samorząd terytorialny we właściwym rozumieniu tego pojęcia. Również pomoc społeczna 
(opieka społeczna) była zmarginalizowana. Znacząca zmiana tej sytuacji przypada na czas przemian ustrojowych zapoczątkowanych w 1989 roku. Pojawienie się nowej ustawy z zakresu zabezpieczenia społecznego ma związek nie tylko z koniecznością zorganizowania systemu wsparcia dla osób i rodzin najbardziej poszkodowanych w wyników dość gwałtownej i radykalnej zmiany zasad funkcjonowania polskiej gospodarki. Zapewne konieczność złagodzenia bolesnych reform wymusiła uchwalenie nowych przepisów i zmianę swoistej filozofii zabezpieczenia społecznego z „opieki”, która była umocowana w nazwie ustawy z 1923 roku na „pomoc”, która znalazła się w nazwie nowej ustawy uchwalonej 29 listopada 1990 roku. Trzeba jednak widzieć tę ustawę także w kontekście przyjętej 8 marca 1990 roku ustawy o samorządzie gminnym. Ona to bowiem w art. 7 ust. 1, p. 6 stwierdzała, że należące do zadań własnych gminy zaspokajanie zbiorowych potrzeb wspólnoty obejmuje sprawy pomocy społecznej, a w tym ośrodków i zakładów opiekuńczych. Natomiast ustawą z dnia 17 maja 1990 r. o podziale zadań i kompetencji określonych $w$ ustawach szczególnych pomiędzy organy gminy a organy administracji rządowej oraz o zmianie niektórych ustaw dokonano zmian w obowiązującej jeszcze formalnie ustawie z 1923 roku. Cytowany już art. 5 tej ustawy określający zadania gminy otrzymał brzmienie: ,gminy sprawują opiekę środowiskową (pozazakładową) w ramach zadań własnych i zleconych; w ramach zadań własnych udzielają zasiłków celowych świadczeń niepieniężnych oraz utrzymują bazę materialno-techniczną ośrodków pomocy społecznej, a także zakładają i utrzymują żłobki i inne zakłady opiekuńcze o zasięgu lokalnym; w ramach zadań zleconych gminy udzielają zasiłków stałych i okresowych oraz finansują wynagrodzenie pracowników socjalnych". Ta objętościowo niewielka zmiana wprowadziła do systemu instytucję ośrodka pomocy społecznej i funkcjonujący do dziś - choć w innych proporcjach - podział zadań na własne i zlecone.

Fundamentem nowoczesnej pomocy społecznej, a zarazem podstawa jej decentralizacji i ulokalnienia stała się uchwalona 29 listopada 1990 roku ustawa o pomocy społecznej. Zgodnie $\mathrm{z}$ art. 9 tejże ustawy obowiązek wykonania zadań pomocy społecznej spoczywa na gminie oraz na administracji rządowej w zakresie określonym ustawami. Gmina nie może odmówić pomocy osobie potrzebującej, nawet gdy istnieje obowiązek osób fizycznych lub prawnych do zaspokojenia jej niezbędnych potrzeb życiowych. Część zadań własnych przypisanych gminie miała charakter obligatoryjny, zaś część fakultatywny. Do obowiązkowych zaliczono udzielanie schronienia, posiłku i niezbędnego ubrania osobom tego pozbawionym, świadczenie usług opiekuńczych w miejscu zamieszkania osobom samotnym, pokrywanie kosztów leczenia beneficjentów nieubezpieczonych, pracę socjalna, sprawienie pogrzebu oraz zapewnienie środków na wynagrodzenia pracowników i realizację tych zadań. Wśród gminnych zadań fakultatywnych znalazły się: prowadzenie lokalnych domów pomocy społecznej i ośrodków opiekuńczych, wypłacanie zasiłków celowych, pomoc rzeczowa oraz wykonywanie innych zadań wynikających z rozeznanych potrzeb gminy. I na realizację tych zadań gmina powinna również zapewnić środki (art. 10). W grupie zadań zleconych, a zatem tych, które miały być finansowane z budżetu centralnego znalazły się: świadczenie usług opiekuńczych osobom, którym rodzina nie jest w stanie zapewnić opieki, pomoc na ekonomiczne usamodzielnienie (w naturze i w formie zasiłku lub pożyczki), wyplacanie zasiłków stałych i okresowych, utworzenie i utrzymanie ośrodka pomocy społecznej oraz inne zadania wynikające z rządowych programów pomocy społecznej (art. 11). 
Zdaniem Jerzego Krzyszkowskiego, okres zapoczątkowany wejściem w życie ustawy o pomocy społecznej i trwający do drugiej reformy administracyjnej (1999) „trzeba nazwać niedokończoną decentralizacją pomocy społecznej" (Krzyszkowski, 2005, s. 146), zaś tak ukształtowany system można określić jako trzysegmentowy o charakterze hierarchicznym (Kerlin, 2002/2003, s. 134). Na te trzy segmenty składały się: Ministerstwo Pracy i Polityki Socjalnej, 49 Wojewódzkich Zespołów Pomocy Społecznej oraz 2489 Gminnych i Miejskich Ośrodków Pomocy Społecznej. Ministerstwo nadzorowało WZPS-y, a te kontrolowały i wspierały ośrodki pomocy społecznej. W efekcie system stawał się coraz bardziej zbiurokratyzowany, skoncentrowany na dystrybucji środków finansowych i kontroli administracyjnej procedur przyznawania i wypłacania świadczeń (Krzyszkowski, 2005, s. 146). Jak pisze Dariusz Zalewski „,można rozsądnie argumentować, że u podłoża decentralizacyjnych zmian w obszarze opieki i pomocy społecznej leżały w równej mierze względy merytoryczne, jak i polityczne, tj. racjonalizacja wydatków publicznych i podnoszenie ich efektywności wykorzystania oraz chęć rozłożenia odpowiedzialności za sferę publiczną między podmiotami państwowymi (rządowymi) a samorządowymi" (Zalewski, 2005, s. 145-146). Nie udało się jednak uniknąć problemów w praktycznej realizacji przyjętych założeń.

Zdaniem niektórych autorów tworzony od początku lat 90. ubiegłego wieku system pomocy społecznej był w pewnym sensie zbyt nowoczesny, albowiem nieadekwatny do rzeczywistych możliwości finansowych i kadrowych gmin. Zabrakło też wdrożenia mechanizmów współpracy i koordynacji różnych służb i instytucji. Jak zatem stwierdza Izabela Rybka, ,sprawdził się również czarny scenariusz dotyczący dysfunkcjonalności pomocy społecznej wskutek przeciążenia jej liczbą zadań. W latach 90. systematycznie rozszerzano zakres podmiotowy pomocy społecznej, wprowadzano nowe świadczenia oraz programy pomocowe. Na pomoc społeczną nałożono odpowiedzialność za rozwiązywanie problemów, które wynikały z braku polityki rodzinnej, ograniczenia funkcji wychowawczych i socjalnych szkoły, wadliwego funkcjonowania opieki zdrowotnej i polityki mieszkaniowej” (Rybka, 2006, s. 6). Następowało systematyczne przesuwanie do pomocy społecznej kolejnych grup klientów i powierzanie jej kolejnych zadań, zaś sama pomoc społeczna ,przed tym procesem specjalnie się nie broniła” (Rymsza, 2002, s. 102). Dotyczy to w sposób szczególny gminnej pomocy społecznej, gdyż Wojewódzkie Zespoły Pomocy Społecznej były niejako dalej od problemów jednostek i rodzin.

Słuszna i zgodna z panującymi w systemach pomocy społecznej innych krajów tendencja do decentralizacji napotkała zatem w Polsce pewne bariery, które spowodowały, że niemożliwa była pełna realizacja przyjętych założeń. Niemniej jednak bilans przeprowadzanych w pomocy społecznej zmian w tym okresie może być uznany za dodatni. Jak bowiem pisze Marek Rymsza ośrodki pomocy społecznej stały się instytucją rozpoznawalną w środowiskach lokalnych, zaś wspólpraca pomiędzy nimi a nadzorującymi je wojewódzkimi zespołami pomocy społecznej układała się dobrze (Ibidem, s. 100). Tyle tylko, że jak wspomniano, decentralizacja ta była niepełna.

\section{Reforma administracyjna 1999 roku i jej wplyw na system pomocy spolecznej}

Wdrożona 1 stycznia 1999 roku reforma administracyjna przyniosła przede wszystkim wprowadzenie dwóch kolejnych szczebli samorządu terytorialnego: powiatowego 
i wojewódzkiego. Miała ona wyeliminować „wady niedokończonej decentralizacji z lat 1990-1998" (Krzyszkowski, 2005, s. 147). Na szczeblu powiatowym utworzono Powiatowe Centra Pomocy Rodzinie, zaś na szczeblu województwa samorządowego powołane zostały Regionalne Ośrodki Polityki Społecznej. Powiaty przejęly większość zadań, które przed reformą były realizowane przez wojewódzkie zespoły pomocy społecznej. Miał to być element dalszego przekazywania uprawnień decyzyjnych na niższe szczeble administracji. Zdaniem przeciwników tych rozwiązań były one bardzo kosztowne i prowadziły do zwiększenia liczby urzędników (Zalewski, 2005, s. 149). Sama w sobie reforma administracyjna nie wprowadziła nowych zadań z obszaru pomocy społecznej dla gmin. Niemniej jednak pojawienie się nowych bytów instytucjonalnych $w$ systemie zrodziło kwestię relacji pomiędzy nimi a dotychczas istniejącymi w gminach ośrodkami pomocy społecznej.

Drugi etap decentralizacji charakteryzował się takim sposobem przekazywania zadań publicznych od państwa do samorządowego województwa i powiatu, aby te nowo utworzone szczeble samorządu nie kontrolowały gmin (Rymsza, 2002, s. 103). W szczególności ważne są w tym kontekście różnice pomiędzy ośrodkami gminnymi a powiatowymi centrami pomocy rodzinie. W zakresie poziomu pomocy gminie przypisane zostały świadczenia podstawowe, zaś powiatom specjalistyczne. Gminne ośrodki udzielają wszystkich typów świadczeń, ale znaczącą ich część stanowią świadczenia pieniężne. Powiatowe Centra Pomocy Rodzinie skupiają się na poradnictwie, organizowaniu usług specjalistycznych i opieki zastępczej, zaś ich świadczenia pieniężne ograniczają się wyłącznie do świadczeń dla rodzin zastępczych. W większości przypadków świadczenia OPS opierają się na kryterium dochodowym, zaś PCPR generalnie nie stosują kryterium dochodowego. OPS koncentruje się na działaniach interwencyjnych, naprawczych, zaś wsparcie ma charakter opiekuńczy lub skierowany na usamodzielnianie klientów. PCPR powinien koncentrować się na programach profilaktycznych. Pewna różnica występuje także na poziomie metod interwencji socjalnej. O ile w ośrodkach gminnych możliwe jest stosowanie wszystkich metod pracy socjalnej (choć dominuje case work), o tyle PCPR powinien stosować metodę pracy środowiskowej, rozumianej jako organizowanie i aktywizację społeczności lokalnej (Ibidem, s. 103-104). Można zatem stwierdzić, że wyższe szczeble samorządu nie tylko nie kontroluja/nadzorują gmin w zakresie pomocy społecznej, ale raczej spełniają inne zadania, z których realizacją gminy mogłyby mieć problemy.

Zdaniem krytyków reforma administracyjna wdrożona w 1999 roku nie została przygotowana w sposób należyty. Jerzy Krzyszkowski twierdzi, że „ogólnikowo określono zakres, kompetencje i środki, brak było wzorów nowych organizacji i wzorów ich działania. Kadra nie została przygotowana do realizacji nałożonych na nią zadań, a także wystąpił opór pewnej części sił politycznych i ekspertów przeciw reformie" (Krzyszkowski, 2005, s. 147). W konsekwencji można mówić o trzech rodzajach skutków reformy administracyjnej w odniesieniu do zadań pomocy społecznej. Polityką chybioną okazała się polityka fiskalna, gdyż decentralizacji zadań nie towarzyszyło adekwatne do potrzeb przekształcenie systemu podatkowego. Zabrakło więc decentralizacji finansów. Polityką przeciwskuteczną okazało się wyodrębnienie 65 tzw. powiatów grodzkich, których sytuacja finansowa była w efekcie znacząco lepsza od sytuacji powiatów ziemskich. Miasta na prawach powiatu funkcjonujące jednocześnie jako powiaty i jako gminy miały możliwość transferu środków finansowych niejako pomiędzy budżetami obu szczebli samorządu. Przykładem polityki trafnej, zgodnej z oczekiwaniami jest natomiast współpraca 
jednostek powiatowych $\mathrm{z}$ innymi jednostkami lokalnymi. W tym zakresie szczególnie istotne jest, że same ośrodki gminne wskazały na wiele form współpracy z PCPR (zob. Kerlin, 2002/2003, s. 142-176).

Kilkuletni okres funkcjonowania pomocy społecznej po reformie administracyjnej ukazal zatem szereg problemów, na co odpowiedzią było uchwalenie zupełnie nowej ustawy o pomocy społecznej z dnia 12 marca 2004 roku. Ustawa ta wprowadziła zarazem dość istotne zmiany w gminnej pomocy społecznej. Jak odnotował Dariusz Zalewski, zmiany te ,pogłębiają uruchomiony na początku lat 90 . ubiegłego wieku proces ulokalnienia systemu opiekuńczo-pomocowego. Temu m.in. służy ustawowe przeniesienie zasiłków okresowych do obligatoryjnych zadań własnych gmin czy też nadanie świadczeniom rodzinnym charakteru pomocowego (z zastosowaniem kryterium dochodowego) i uczynienie de facto ośrodków pomocy społecznej odpowiedzialnymi za ich dystrybucję" (Zalewski, 2005, s. 155). Uwzględnić też trzeba pojawienie się innych ustaw, które dotyczą różnych form pomagania potrzebującym i stwarzają możliwość powołania nowych instytucji na szczeblu gminnym. Przykładem może być ustawa z dnia 13 czerwca 2003 roku o zatrudnieniu socjalnym, na mocy której tworzone są centra integracji społecznej i kluby integracji społecznej, czyli podmioty realizujące model aktywizującej polityki i pomocy społecznej.

Analizując okres funkcjonowania pomocy społecznej po 1 stycznia 1999 roku Piotr Błędowski i Paweł Kubicki zauważają zdecydowany wzrost roli budżetu samorządów w finansowaniu środowiskowej pomocy społecznej. W 2000 roku udział wydatków samorządowych wynosił 1/3, w 2004 roku osiagnął 2/3, zaś w 2008 było to już 3/4 ogótu wydatków na świadczenia środowiskowej pomocy społecznej. I autorzy konkludują że „pomoc społeczna stała się - obok oświaty - głównym zadaniem finansowanym z budżetu gminy" (Błędowski, Kubicki, 2009, s. 41). Na dłuższą metę jest to sytuacja bardzo niekorzystna, gdyż przecież poza oświatą i właśnie pomocą społeczną gminy mają wiele jeszcze innych istotnych zadań do zrealizowania i na zadania te muszą znajdować w swych budżetach odpowiednie środki. Trzeba przy tym dodać, że rosnącej roli pomocy społecznej w takim sensie jak wyżej zasygnalizowany, nie towarzyszy realny wzrost pozycji społecznej tej instytucji ani prestiżu jej pracowników.

\section{Aktualne wyzwania dla gminnej pomocy spolecznej}

Obserwując dokonywane i planowane zmiany w systemie pomocy społecznej, nie tylko na poziomie gminy, ale na wszystkich szczeblach administracji, stwierdzić można, iż proces transformacji tego systemu jeszcze się nie zakończył. Aktualne pozostają uwagi dotyczące wyzwań stojących przed pomocą społeczną jakie kilka lat temu sformułowali Joanna Staręga-Piasek oraz cytowani już Piotr Błędowski i Paweł Kubicki.

J. Staręga Piasek (2006, s. 94-96) zwróciła uwagę na dwojakiego rodzaju bariery utrudniające skuteczne funkcjonowanie zdecentralizowanej pomocy społecznej w Polsce, mianowicie bariery zewnętrzne i bariery wewnętrzne. W kontekście funkcjonowania pomocy społecznej jako instytucji samorządu gminnego szczególne znaczenie mają bariery zewnętrzne. Zdaniem autorki do tych barier zewnętrznych zaliczyć trzeba przede wszystkim problemy we współpracy między poszczególnymi szczeblami administracji 
samorządowej. Brakuje również dobrych mechanizmów współpracy pomiędzy pomocą społeczną a innymi instytucjami na terenie danej jednostki samorządu terytorialnego, takimi jak sądy, urzędy pracy, szkoły, służba zdrowia. Autorka wskazuje też na traktowanie wydatków na pomoc społeczną jako marnotrawstwo środków, zamiast postrzegania ich w kategoriach inwestycji społecznych. Istotną barierą zewnętrzną jest też brak w samorządach rzeczywistej przychylności dla współpracy z organizacjami pozarządowymi. Na poziomie samorządów odtwarzane są sektorowe struktury administracji rządowej, co utrudniania integrację działań i w efekcie blokuje skuteczne rozwiązywanie problemów społecznych. Część „winy” za niedoskonałe funkcjonowanie gminnej pomocy społecznej tkwi jednakże w niej samej, gdyż bariery wewnętrzne są pochodną przyjętych reguł działania pomocy społecznej oraz jakości tworzących tę instytucję zasobów ludzkich. Do owych barier wewnętrznych Staręga-Piasek zaliczyła najpierw brak współdziałania między różnymi instytucjami pomocy społecznej i szczeblami samorządowymi (powiatowe centra pomocy rodzinie, gminne ośrodki pomocy społecznej, domy dziecka, domy pomocy społecznej). Ponadto dostrzegła nieumiejętność planowania długookresowego i fikcyjność strategii rozwiązywania problemów społecznych. Brakuje także właściwych mechanizmów nadzoru i kontroli zarówno działalności, jak i skuteczności pomocy społecznej. Sama pomoc społeczna jest niechętna - mimo dość dobrych rozwiązań legislacyjnych - współpracy z sektorem pozarządowym. Autorka zauważa niechęć do innowacyjności i ryzyka, brak lub niski poziom wymiany informacji między instytucjami lokalnymi, a także brak lokalnych liderów zdolnych do wprowadzania nowych rozwiązań i integrowania środowiska lokalnego. Wśród barier wewnętrznych wymieniony został brak pozytywnego klimatu wobec instytucji pomocy społecznej, choć to akurat może być także barierą zewnętrzną.

Piotr Błędowski i Paweł Kubicki zwrócili z kolei uwagę na kilka szczególnych wyzwań, przed jakimi staje gminna pomoc społeczna (Błędowski, Kubicki, 2009, s. 43). Za najważniejsze uznali konieczność współpracy z innymi lokalnymi instytucjami, szczególnie z powiatowymi urzędami pracy. Wynika to z konieczności realizacji paradygmatu aktywizacji beneficjentów wsparcia. Trudność tkwi w rozbieżności adresatów działań tych instytucji: urzędy pracy skupiają się na tych, których można skutecznie zaktywizować, zaś ośrodki pomocy społecznej na osobach w najtrudniejszym położeniu materialnym, o częstokroć znacznie ograniczonych możliwościach aktywizacji. Drugim wyzwaniem jest zdaniem autorów organizacja usług opiekuńczych dla osób niesamodzielnych. Rosnąca liczba takich osób (długotrwale chorych, niepełnosprawnych) sprawia, że sama publiczna (a zatem lokalna, przede wszystkim gminna) pomoc społeczna w niewielkim stopniu może sprostać zapotrzebowaniu. Tu otwiera się pole dla zlecania tych zadań innymi podmiotom na większą skale, ale na przeszkodzie stanie w pewnym momencie ograniczony budżet. Trzecie wyzwanie dotyczy tworzenia i utrzymywania infrastruktury domów pomocy społecznej. Ma to związek ze wspomnianą dużą liczbą osób niesamodzielnych, spośród których pewnej części nie można zapewnić usług opiekuńczych w miejscu zamieszkania. I wreszcie czwartym, bardzo poważnym wyzwaniem jest zauważalna wyraźna dominacja świadczeń pieniężnych i ograniczenie się przez ośrodki pomocy społecznej do tych osób potrzebujących, które lokują się poniżej kryterium dochodowego. $Z$ tym związane są zaniedbania w realizacji pracy socjalnej, jak również fakt, że w niektórych gminach brakuje pracowników socjalnych. 
Decydenci pomocy społecznej w Polsce zdają się być świadomi wyzwań i trudności, przed jakimi staje ta instytucja, stąd też w ostatnich kilku latach pojawiło się kilka założeń do reformy systemu, niekiedy proponujących dość daleko idące zmiany. Nie ma tu oczywiście miejsca na dokładną analizę proponowanych rozwiązań, ale warto wskazać na niektóre propozycje dotyczace pomocy społecznej na poziomie gminy ${ }^{1}$. W kwietniu 2013 roku pojawiła się zatem koncepcja przeformułowania celów pomocy społecznej w taki sposób, aby wyraźnie wskazać na priorytet działań profilaktycznych i aktywizujących, a także kluczową rolę usług socjalnych. Miałoby to służyć rzeczywistemu zapobieganiu powstawaniu i pogłębianiu się zjawisk dysfunkcyjnych. Nowym rozwiązaniem w ramach usług interwencyjnych miałyby być tzw. sąsiedzkie usługi opiekuńcze. W konsekwencji pojawiłaby się nowa struktura organizacyjna pomocy społecznej w gminie pod nazwą „Centrum Pomocy i Usług Socjalnych”. Samorząd otrzymałby swobodę w dopasowaniu wewnętrznej struktury organizacyjnej jednostek pomocy społecznej w taki sposób, aby możliwe było rozdzielenie zadań administracyjnych (głównie przyznawania i wypłaty świadczeń) od realizowania pracy socjalnej i świadczenia usług socjalnych. Obligatoryjnymi działami Centrum Pomocy i Usług Socjalnych byłyby zatem Dział Pracy Socjalnej i Dział Usług Socjalnych. Dział zajmujący się obsługą administracyjną i księgowo-finansową mógłby być utworzony wewnątrz Centrum lub poza nim, w strukturach urzędu gminy. W założeniach $\mathrm{z}$ marca 2014 roku przytoczone propozycje zostały generalnie podtrzymane, ale wypadł z projektu pomysł utworzenia Centrum Pomocy i Usług Socjalnych. Ośrodek Pomocy Społecznej pozostał podstawową strukturą tej instytucji na szczeblu gminy i to w jego ramach miałyby funkcjonować Dział Pracy Socjalnej i Dział Usług Socjalnych. Dodano jednakże akapit, zgodnie z którym w przypadku małych gmin, czyli takich gdzie obsada kadrowa ośrodka pomocy społecznej jest niewielka, zaproponowano alternatywnie wyodrębnienie stanowiska do spraw pracy socjalnej, stanowiska do spraw usług socjalnych i fakultatywnie stanowiska do spraw wsparcia dochodowego.

W sierpniu 2014 roku pojawily się dwa warianty założeń i w przytoczonym zakresie obydwa podtrzymują propozycje organizacyjne z marca $2014 \mathrm{r}$.

Propozycje te wychodzą naprzeciw postulatom dowartościowania pracy socjalnej i zdjęcia z gminnej pomocy społecznej odium instytucji zajmującej się wyłącznie wypłatami zasiłków. Aktywizacja beneficjentów przynieść powinna wzrost efektywności udzielanego wsparcia rozumianej jako realne wyprowadzanie osób i rodzin z trudnych sytuacji życiowych. Zapewne też oczekiwanym skutkiem zmian jest racjonalizacja wydatków na cele socjalne, co nabiera szczególnego znaczenia w kontekście sposobu finansowania i zakresu zadań realizowanych przez pomoc społeczną na szczeblu gminy.

\section{Zakończenie}

Jak wynika $\mathrm{z}$ analiz przedstawionych $\mathrm{w}$ prezentowanym tekście, gminna pomoc społeczna posiada w Polsce tradycje i doświadczenia sięgające okresu dwudziestolecia

Projekty tych zmian znajdują się na stronach Ministerstwa Pracy i Polityki Spolecznej, pod adresem http:/www.mpips.gov.pl/bip/projekty-aktow-prawnych/projekty-ustaw/pomoc-spoleczna/projekt-zalozen-projektu-ustawy-o-zmianie-ustawy-o-pomocy-spolecznej-oraz-niektorych-innych-ustaw- $/$. 
międzywojennego. Odrodziła się ona u początków transformacji ustrojowej w ślad za restytucją samorządu terytorialnego na szczeblu gminnym. Pierwszy okres przypadający na lata 90. ubiegłego wieku był czasem niepełnej decentralizacji tej instytucji. Jej dopełnieniem miała być reforma administracyjna wdrożona w roku 1999. Gminna pomoc społeczna ugruntowała w tym czasie swoje miejsce jako podstawowa instytucja zabezpieczenia społecznego na szczeblu lokalnym. Doświadczyła jednakże coraz dalej idącego spychania na nią kolejnych zadań, bez zapewnienia niezbędnych środków finansowych na ich realizację. Skutkiem są kolejne koncepcje reformowania tej instytucji, tym razem zmierzające w stronę rozdzielenia zadań administracyjnych od bezpośredniego wspierania potrzebujących.

\section{Bibliografia}

Błędowski P., Kubicki P. (2009), Pomoc spoleczna - glówna instytucja socjalna na szczeblu lokalnym, „Polityka Społeczna”, nr 11-12.

Kamiński T. (2012), Caritas i polityka. Podmioty wyznaniowe w systemie pomocy spolecznej, Wydawnictwo Uniwersytetu Kardynała Stefana Wyszyńskiego, Warszawa.

Kaźmierczak T. (2000), Pomoc społeczna, w: Encyklopedia socjologii, t. 3, Oficyna Naukowa, Warszawa.

Kerlin J. (2002/2003), Pomoc spoleczna po reformie administracyjnej 1999 r: Analiza polityki i jej skutków, w: Pomoc spoteczna. Od klientyzmu do partycypacji, red. E. Leś, ASPRA-JR, Warszawa.

Krzyszkowski J. (2005), Między państwem opiekuńczym a opiekuńczym spoleczeństwem. Determinanty funkcjonowania środowiskowej pomocy społecznej na poziomie lokalnym, Wydawnictwo Uniwersytetu Lódzkiego, Lódź.

Księżpolski M. (1999), Polityka spoleczna. Wybrane problemy porównań międzynarodowych, Wydawnictwo Naukowe Śląsk, Katowice.

Maciejko W. (2009), Instytucje pomocy spolecznej, LexisNexis, Warszawa.

Rybka I. (2006), Diagnoza pomocy spolecznej w Polsce w latach 1991-2006. Możliwości i bariery zastosowania instrumentów ekonomii spolecznej w pomocy spolecznej, http://www.ekonomiaspoleczna.pl/files/ekonomiaspoleczna.pl/public/Biblioteka/2006.21.pdf, 12 maja 2015.

Rymsza M. (2002), Praca socjalna i pracownicy socjalni po reformie samorzqdowej z 1999 roku, w. Wielowymiarowość pracy socjalnej, red. K. Frysztacki, K. Piątek, Wydawnictwo Edukacyjne Akapit, Torun.

Skidmore R. A., Thackeray M. G. (1996), Wprowadzenie do pracy socjalnej, Interart, Warszawa.

Staręga-Piasek J. (2006), Przyczynek do decentralizacji pomocy spolecznej, w: Nowe dylematy polityki spotecznej, red. S. Golinowska, M. Boni, Nowe dylematy polityki spotecznej, Centrum Analiz Społeczno-Ekonomicznych, Warszawa.

Zalewski D. (2005), Opieka i pomoc spoleczna. Dynamika instytucji, Wydawnictwa Uniwersytetu Warszawskiego, Warszawa.

\section{Municipal social welfare - twenty five years of transformation}

\section{Summary}

The paper is devoted to reflections on the functioning of social welfare in the restored structures of local government in last twenty-five years. Firstly, it generally shows the importance of decentralisation 
processes in contemporary social welfare. Then it briefly presents the experiences of Polish municipal social welfare, on the basis of the Social Welfare Act adopted in 1923. Next, it presents the key role of the Social Assistance Act of 29 November 1990, the effects of the administrative reform implemented on 1 January 1999 and the current challenges facing municipal social welfare.

Key words: municipality, social welfare, decentralisation 